\section{Democracia digital e experiências de e-participação: webativismo e políticas públicas}

\author{
Digital democracy and \\ experiences in e-participation: \\ Internet activism and public \\ policy \\ Rafael de Paula Aguiar Araújo \\ Professor, Pontifícia Universidade Católica de São Paulo e \\ Escola de Sociologia e Política de São Paulo. \\ Fundação Escola de Sociologia e Política de São Paulo \\ Rua General Jardim, 522 \\ 01223-010 - São Paulo - SP - Brasil \\ rafa77@uol.com.br
}

\section{Cláudio Luis Camargo Penteado}

Professor, Centro de Engenharia, Modelagem e Ciências Sociais Aplicadas/Universidade Federal do ABC. Avenida dos Estados, 5001

09210-170 - Santo André - SP - Brasil

claudio.penteado@ufabc.edu.br

\section{Marcelo Burgos Pimentel dos Santos \\ Professor, Departamento de Ciências Sociais/ Universidade Federal da Paraíba. \\ Centro de Ciências Humanas, Cidade Universitária, Letras e Artes - Campus I \\ 58051-900 - João Pessoa - PB - Brasil \\ marceloburgos@cchla.ufpb.br}

Recebido para publicação em outubro de 2014.

Aprovado para publicação em abril de 2015.

http://dx.doi.org/10.1590/S0104-59702015000500004
ARAÚJO, Rafael de Paula Aguiar; PENTEADO, Cláudio Luis Camargo; SANTOS, Marcelo Burgos Pimentel dos. Democracia digital e experiências de e-participação: webativismo e políticas públicas. História, Ciências, Saúde Manguinhos, Rio de Janeiro, v.22, supl., dez. 2015, p.1597-1619.

\section{Resumo}

O objetivo aqui é auferir os processos de articulação entre o Estado e a sociedade civil, avaliando a importância de diferentes estratégias de mobilização empreendidas por distintas organizações sociais que atuam na cidade de São Paulo. Analisa-se a influência do uso das tecnologias de informação e comunicação (TICs) no desenvolvimento de políticas públicas como meio capaz de formar a opinião dos cidadãos e estabelecer demandas. Aplicando o Índice de Participação Política e Influência, foram avaliadas experiências de webativismo em São Paulo. Os resultados apontam que movimentos e coletivos com maior inventividade e variedade de estratégias em suas ações tiveram melhores desempenhos, sinalizando um novo modo de ação da política contemporânea.

Palavras-chave: políticas públicas; participação política; democracia; webativismo.

\section{Abstract}

The article explores processes of interaction between the State and organized civil society in an effort to assess the weight of the various social mobilization strategies utilized by different social organizations active in the city of São Paulo. The study is particularly interested in analyzing how the use of information and communications technology (ICT) influences the development of public policy as a means for shaping citizen opinion and establishing demands. A Political Participation and Influence Index was used to evaluate experiences in Internet activism in the city of São Paulo. Findings suggest that the movements and collectivities with the most inventive and broadest diversity of strategies achieve better results, signaling a new method of action in contemporary politics.

Keywords: public policy; political participation; democracy; Internet activism. 
A s tecnologias de informação e comunicação (TICs) ganham destaque na sociedade contemporânea por contribuir significativamente para alterações nas relações sociais em diversos sentidos. As TICs têm modificado o processo de produção de bens materiais e imateriais; exercido influência direta nos sistemas políticos, ao possibilitar novas formas de atuação e ação; e produzido novos valores sociais, culturais, econômicos ou políticos. As transformações não são apenas no modo de desenvolvimento das políticas institucionais, mas também na forma como outras arenas públicas têm sido ocupadas. Nesse sentido, os protestos no Brasil ocorridos nos meses de junho e julho de 2013 são exemplares.

O intenso uso das tecnologias abriu novas possibilidades para que a sociedade civil pudesse ampliar sua participação ativa na vida pública, aumentando a capacidade de mobilização e a articulação dos cidadãos, possibilitando um maior envolvimento dos atores sociais. Além disso, a própria produção de informação e a disputa pela formação da opinião foram transformadas, deixaram de ser unidirecionais e verticais (como na mídia tradicional), passando a ser multidirecionais e horizontais. Mesmo que de maneira não explícita, pode-se afirmar que a sociedade e a política passam por reconfigurações mediatizadas por aparatos digitais (Pinho, 2012). Em outras palavras, a internet contribui para novos processos de relacionamentos e vivências. Joan Subirats (2011, p.6) afirma:

Se queremos uma democracia viva, se queremos uma política compartilhada, necessitamos de espaços e oportunidades que permitam debates abertos, onde se construam ideais e visões também compartilhados. Espaços em que todos e cada um possam intervir. Essas são as bases para poder falar de cidadania, de inclusão social, de uma nova relação com a natureza. Em definitivo, uma sociedade em que valha a pena viver. ${ }^{1}$

Nos últimos anos podem ser observadas diversas mudanças nas relações entre Estado e sociedade civil. Novos arranjos societais implicam um novo modus operandi a partir de algumas características da sociedade civil contemporânea, como fragmentação, complexidade e pluralidade. Por outro lado, o Estado também passa por mudanças significativas em sua organização e seu funcionamento, principalmente após anos de governos neoliberais no Ocidente. O enfraquecimento do Estado também auxilia o crescimento e desenvolvimento da organização da sociedade civil. Com isso, esses novos arranjos institucionais e sociais ampliam significativamente os espaços de participação cidadã.

Nessa perspectiva, a arquitetura em rede da internet, somada às ferramentas de interação, tem possibilitado uma criativa agenda de ações políticas, que podem significar um avanço no desenvolvimento dos processos democráticos. Essas tecnologias possibilitam novos mecanismos de comunicação com o Estado e viabilizam diferentes articulações da sociedade civil. As TICs, nesse sentido, têm sido usadas por órgãos e instituições estatais, mas também por indivíduos e grupos sociais organizados da sociedade, como forma de ampliação da esfera pública e da arena política, numa via de mão dupla (Subirats, 2011; Pinho, 2012; Brugué, 2009).

O Estado e a sociedade civil se apropriam dessas ferramentas para fazer valerem seus pontos de vista e articulações políticas. Quando as ações partem do Estado para a sociedade civil, ficam conhecidas como modelos top-down, ou seja, de cima para baixo. Quando, ao contrário, partem da sociedade civil para o Estado, o modelo é denominado de bottom-up, de baixo para cima. Ambos são muito utilizados para pensar o fazer político e a participação 
democrática. Atualmente, na literatura da ciência política, têm sido encarados como modelos de discussão e implementação das políticas públicas (Avritzer, 2008; Brugué, 2009; Macintosh, Whyte, 2008; Pérez, 2009). Assim, quanto maior o diálogo ou contatos porosos entre Estado e sociedade civil, mais se definem como democráticas as políticas adotadas ou realizadas.

As movimentações sociais, no atual estágio de desenvolvimento da tecnologia e do sistema capitalista, procuram novas estratégias de ação e reordenamentos. Nesse sentido, a avaliação do uso da internet na articulação das ações políticas é fundamental para a compreensão da cidade tecno-científica-informacional e das estruturas de resistência e intervenção que são gestadas como meio para o empoderamento do cidadão. Este artigo objetiva auferir os processos de articulação entre a sociedade civil organizada e o Estado, especialmente no que tange os aspectos de participação cidadã no ciclo de políticas públicas. Quer, também, avaliar a importância de diversas estratégias de mobilização social empreendidas por diferentes organizações sociais. Trata-se, assim, de dar materialidade à relação entre a política institucional e o uso das TICs como meio de intervenção e participação democrática.

Especificamente, analisa-se, aqui, de que forma ocorre a influência do uso das TICs no ciclo de desenvolvimento de políticas públicas, como meio capaz de formar a opinião dos cidadãos e estabelecer demandas da sociedade civil. O webativismo aparece como estratégia de articulação e de exercício de pressão, ampliando a possibilidade de o Estado incluir as demandas em sua agenda e, em alguns casos, modificar os processos decisórios e de implementação de políticas. A análise dessas ações e de seus impactos pode permitir maior caracterização dessa nova forma de participação política. Parte-se do princípio de que, da mesma forma que o Estado se vale dos meios de comunicação para pautar a agenda e auferir informações importantes sobre os impactos das ações desenvolvidas, a sociedade civil, mediante os meios digitais, o uso de recursos e de articulações, estabelece (ou tenta estabelecer) uma pauta de discussões capaz de suscitar demandas ao Estado e direcionar a formulação de políticas públicas.

Nos últimos anos são inúmeros os exemplos de ações que, por meio dos dispositivos digitais, exerceram influência no desenvolvimento de políticas. O próprio Estado, ao perceber as possibilidades de uso dessas ferramentas como instrumento político, tem procurado criar espaços para ampliar a participação cidadã. No Brasil, um exemplo disso é a criação do projeto E-Democracia pela Câmara dos Deputados (http://edemocracia.camara.gov.br/), pelo qual qualquer cidadão encontra espaço para sugerir e debater propostas que podem ser discutidas no Congresso Nacional, ampliando a possibilidade do exercício democrático. Mais recentemente, o Poder Executivo federal criou o Portal da Participação Social (http://www.psocial.sg.gov. br), tentando estimular um novo método de governo, como ali afirmado. Vale lembrar que no governo Lula (2003-2010) houve várias experiências de incentivo à participação política institucional por intermédio do uso das TICs, como, por exemplo, o portal do Ministério da Cultura (Araújo, Penteado, Santos, 2010).

As ações que partem da sociedade civil também encontram espaços de atuação na internet como, por exemplo, o caso do Movimento Cansei (instituído em 2006 e logo depois desfeito), a Rede Nossa São Paulo (Araújo, Penteado, Santos, 2012a, 2012b) ou diversos outros movimentos surgidos ou ampliados pelas redes sociais, especialmente o Twitter e o Facebook. Recentemente, esse fenômeno ganhou destaque no Brasil por diferentes protestos ocorridos desde junho de 2013, iniciados pela elevação da tarifa de transporte urbano, mas que se ampliaram para 
diferentes causas. Esses protestos têm ocorrido em diferentes países, com importantes desfechos políticos, mas este artigo ficará centrado no webativismo ocorrido no Brasil.

\section{Participação política e sociedade civil}

O surgimento de novos espaços virtuais, que incorporam as demandas políticas da sociedade, insere-se em um quadro de crise da democracia representativa (ou da sua legitimidade) com a incorporação das novas ferramentas (TICs) que permitem novos desenhos participativos. Diversos autores e pesquisas têm refletido sobre a democracia representativa e suas dificuldades de legitimação e funcionamento, uma vez que os cidadãos são incentivados a participar apenas no momento eleitoral. Assim, a democracia representativa existe, sobretudo, como participação eleitoral, uma vez que outras possibilidades de participação são limitadas, variando conforme cada regime democrático.

No Brasil, a Constituição Federal de 1988 (CF/88) incentivou a organização da sociedade civil para lutar e reivindicar seus direitos, ampliando a participação política nas decisões do Estado depois de mais de vinte anos de ditadura militar. A partir de então, foram estimuladas as participações da sociedade em diversos conselhos que passam a existir com a intenção de subsidiar encontros, debates e discussões sobre as políticas que deveriam ser adotadas pelo Estado em todas as suas esferas. Exemplo conhecido e estudado dessa iniciativa é a experiência do Orçamento Participativo em Porto Alegre (RS) no início dos anos 1990, que hoje se espalha por diversas cidades do Brasil e do mundo. Atualmente, algumas cidades como Recife e Belo Horizonte têm radicalizado essa experiência, ao adotar o chamado Orçamento Participativo Digital, feito com base na participação on-line.

Uma consequência desse "apoio" constitucional são as leis de iniciativa popular (também contempladas na $\mathrm{CF} / 88$ ) que passaram a existir como possibilidade efetiva na realidade política brasileira. Um exemplo recente é a Lei da Ficha Limpa, sancionada em 2010 (lei complementar 135/2010), mas que foi articulada por organizações da sociedade civil, em forte campanha iniciada em 2008. Apesar de toda a movimentação e apoio, a lei só entrou em vigor de fato após ser analisada e aprovada pelo Supremo Tribunal Federal em 2012.

Os usos da internet pela sociedade civil têm ampliado a participação política, sobretudo depois do advento da Web 2.0. Isso deriva das facilidades com que as informações circulam e atuam na formação da opinião pública e pela possibilidade de se exercer pressão nos gestores públicos para que as demandas da sociedade civil sejam contempladas no campo político. $\mathrm{O}$ que se constata é que a comunicação e a troca de informações deixam de ser unidirecionais (e hierárquicas), de cima para baixo, e tornam-se multidirecionais, transitando por diversos sentidos e caminhos. Isso altera não apenas a forma de fazer política, mas também a própria sociedade. Nos casos analisados neste artigo, as transformações políticase tecnológicas contribuem de alguma forma para a alteração do ciclo de desenvolvimento de políticas públicas. Assim, é preciso uma avaliação cuidadosa, para que se possa realizar um diagnóstico mais preciso sobre essa nova realidade.

A própria ideia de participação política pode ser pensada de diferentes maneiras. Pode fazer referência a cidadãos que estão presentes na política profissional ou em ativismos políticos organizados. A participação política pode associar-se a envolvimentos efetivos na tomada de 
decisões políticas com o exercício de pressão ou com a sugestão de alternativas para diferentes questões que entram na agenda de debates. É possível, portanto, associá-la à participação cidadã. As TICs têm colaborado para ampliar ou incrementar essas possibilidades. Como consequência para os cidadãos, a política aos poucos deixa de ser uma prerrogativa do Estado e passa a incorporar novos atores e práticas, que geram criativas formas de intervenção no processo político. Essa participação é definida por Nogueira (2013, p.156):

A participação política mostra-se, portanto, como uma participação de forte conteúdo cívico, relacionado à pólis. Seu alvo não é a conquista do poder, mas a criação de condições para afirmação de novas formas de poder que sejam capazes de pressionar o poder, os governos e os gestores com pleitos associados à cidadania. Nesse sentido, aproxima-se do que tem sido chamado de "participação cidadã", uma interação complexa e contraditória entre Estado, mercado e sociedade civil que se abre para novas formas de reivindicação, controle social e gestão.

Nesse contexto surgiu uma nova expressão para essa nova prática política: "democracia digital". De acordo com José Eisenberg (2013), a internet vem auxiliando na transformação da democracia participativa por meio (1) da redução do custo da ação coletiva, ao dispor informações e materiais de divulgação de ideias; (2) da redução do custo de participação dos agentes individuais; (3) da formação de novas identidades coletivas mediante espaços temáticos; (4) da horizontalidade da comunicação; (5) da possibilidade de os movimentos sociais avaliarem a repercussão das atividades políticas.

Assim, mesmo que a democracia participativa não esteja plenamente incorporada à sociedade, ela passa a ter presença cada vez mais importante dentro do funcionamento da democracia representativa atual. As redes sociais são convertidas em um novo espaço público que encoraja a participação dos mais variados atores sociais em suas lutas e reivindicações políticas. A velha dicotomia existente entre democracia representativa e democracia participativa pode ser superada pelos novos adventos tecnolóicos. ${ }^{2}$ Nesse sentido, o grupo de pesquisadores procurou dar materialidade a essa nova realidade realizando um mapeamento de diversas experiências de webativismo empreendidas pela sociedade civil, a partir dos filtros apresentados anteriormente.

\section{TICs e participação política}

A relação entre TICs e participação possui múltiplas dimensionalidades e possibilidades analíticas. Uma dessas dimensões está associada à reconstrução do debate sobre o conceito de "capital social", de Robert Putnam (2002, p.177), como um meio de fortalecer a democracia e práticas coletivas. Matos (2007) busca relacionar a cultura de confiança e comportamentos cooperativos (capital social) com a comunicação mediada por computadores. Segundo a autora, para que as ações na internet ganhem viabilidade e se concretizem, é necessário que se desenvolva e se consolide o capital social como um fator responsável por promover a formação de uma comunidade fortemente engajada para a realização de mudanças sociais.

O capital social cria condições para a superação do dilema da ação coletiva, gera um contexto de cooperação para a formação de um sistema cívico de participação, estruturado em regras de confiança e reciprocidade dos membros da comunidade. Sua acumulação 
é feita pela prática de ações coletivas sociais que estimulam a formação de laços sociais. A existência de capital social facilita a cooperação, permite a formação de uma cultura cívica de engajamento e participação pública, e cria um contexto social favorável para a realização de ações que promovam o desenvolvimento social (Putnam, 2002).

Matos (2007) reconhece que existem diferentes posições quanto à possibilidade de a internet criar e fortalecer capital social ou então promover uma corrosão do caráter (Sennett, 1999) por meio da promoção da maior individualidade do tempo livre. A autora identifica quatro polos de estudos do capital social: a confiança, a reciprocidade, a erosão do caráter e as redes sociais (laços sociais) como fatores de acumulação de capital social.

Desses quatro polos, três - confiança, reciprocidade e redes sociais - são elementos que possibilitam a criação de condições favoráveis para o desenvolvimento de ações cívicas que encontram no ciberespaço um lugar para seu desenvolvimento e fortalecimento, amparados por uma cultura digital participativa e colaborativa (Lemos, 2002). No espaço interconectado e estruturado por redes da internet existe a possibilidade do desenvolvimento de práticas colaborativas e interativas que ajudam a construção do capital social, promovendo ações que fomentam a confiança, a reciprocidade e a criação, como o fortalecimento de redes sociais. Um exemplo de cibercultura colaborativa é a Wikipédia, enciclopédia digital coletiva construída com a colaboração dos seus usuários. Outro exemplo é a popularidade das principais redes sociais da internet, especialmente o Facebook e o Twitter, responsáveis por produzir novas formas de sociabilidade, que são tecidas dentro do ambiente virtual, caracterizado por interação e compartilhamento de conteúdos, formando uma cultura da interatividade (Pinezi, Penteado, Silveira, 2012).

Dentro da sociedade organizada no paradigma de rede - a "sociedade em rede" (Castells, 1999, p.497) - as redes sociais se configuram como uma nova morfologia social, que promove uma mudança nos processos produtivos, nas relações de poder e cultura. Nessa nova configuração social e informacional, o espaço digital da internet cria condições para aumentar a concentração de poder e exclusão social; mas, por outro lado, possibilita a tessitura de novas relações sociais desenvolvidas e alimentadas a partir da horizontalidade característica das redes cívicas, que são conectadas on-line e off-line com o intuito de promover o desenvolvimento local (Frey, 2003).

Como aponta Maia (2007), os atores coletivos da sociedade civil se valem dos recursos da internet para promover novas práticas de ação. A autora indica que existem diferentes tipos de redes da sociedade civil operando dentro do ambiente virtual, sendo que muitas delas tentam influenciar o Estado e suas políticas, configurando novas práticas políticas que se estabelecem por meio do uso das TICs. Os atores coletivos cívicos têm utilizado os recursos da internet para diferentes práticas, que Maia (2007, p.47-48) agrupou em quatro tipos de rede: redes para a produção de conhecimento técnico competente (organizar conhecimento para ser empregado pelos movimentos sociais), redes de memória ativa (formação de centros virtuais de informação e comunicação), redes para a produção de recursos comunicativos (produção de recursos para ampliar a capacidade de comunicação e aproveitamento das oportunidades que a internet oferece) e redes de vigilância e solidariedade a distância (desenvolver formas de defesa dos direitos dos cidadãos). 
A partir desses quatro tipos de rede, Maia (2007) identifica quatro diferentes padrões de interação entre os atores coletivos cívicos no ambiente virtual da internet, "para gerar efeitos potencialmente democráticos": (a) interpretação de interesses e construção de identidade coletiva; (b) constituição de esfera pública; (c) ativismo político, embates institucionais e partilha de poder; (d) supervisão e processos de prestação de contas. Esses padrões acabam por modular as formas de atuação on-line das diferentes organizações da sociedade civil em suas mais variadas práticas políticas, sociais, econômicas, culturais, comunicacionais e organizacionais.

Atuando dentro de um novo espaço (ciberespaço) e de um novo paradigma (rede), a sociedade civil organizada, em suas diversas formas, promove novos tipos de ações coletivas, gerando novas formas de ativismo e de empoderamento por meio de articulações em rede e participação política (e-participação). Scherer-Warren (jan.-abr. 2006) destaca que estamos vivenciando um novo formato de organização da sociedade civil: redes de movimentos sociais. Essas redes se articulam em diferentes níveis: associativismo local; formas de articulação interorganizacionais (redes de redes); mobilizações na esfera pública (produzir visibilidade e efeitos simbólicos para os participantes e a sociedade em geral); e captação de recursos materiais de sustentação organizacional.

As redes de movimentos sociais da sociedade globalizada integram diversos atores sociais (nível local e global, diferentes tipos de organizações sociais e diversidade de valores e interesses), que, apesar de haver conflitos internos entre seus participantes, conseguem formatar um sujeito plural que incorpora uma multiplicidade de bandeiras, identidades, valores e projetos, articulados em torno da transversalidade de direitos na luta pela cidadania, por meio do alargamento da concepção de direitos humanos e da ampliação da base das mobilizações (Scherer-Warren, jan.-abr. 2006).

Rompendo com o modelo top-down de engajamento estruturado em iniciativas dos governos de uso das TICs como suporte para participação cidadã, formas inovadoras de atuação da sociedade civil têm sido desenvolvidas no sentido de promover novos meios de participação e empoderamento de entidades e organizações da sociedade, havendo, portanto, a necessidade do desenvolvimento de um modelo de estudo dessas práticas (Macintosh, Whyte, 2008).

A internet oferece diferentes oportunidades para os cidadãos intervirem e atuarem na vida política, criando mecanismos para o desenvolvimento de uma participação on-line (e-participação), pela qual o uso das ferramentas das TICs possibilita o envolvimento da sociedade civil na busca de soluções para alguns dos problemas da sociedade (Meijer, Burger, Ebbers, 2009). Tambouris et al. (2007, p.9), ao estudar experiências europeias de e-participação, identificaram diferente níveis: e-informação (canal de informação para os cidadãos), e-consulta (canal de comunicação on-line para coletar respostas e alternativas do público), e-envolvimento (assegurar que as preocupações públicas sejam compreendidas e levadas em consideração), e-colaboração (canal interativo entre o cidadão e o governo, pelo qual os primeiros podem participar ativamente do desenvolvimento de alternativas e na identificação de soluções preferidas) e e-empoderamento (facilita a transferência da influência, o controle e a formulação de políticas para o público). 
Atento às transformações dos movimentos sociais, Machado (jul.-dez. 2007) identifica que inicialmente os mesmos eram percebidos sob uma visão marxista-estruturalista, como uma manifestação da luta de classes dentro da sociedade capitalista. Contudo, com a proliferação de movimentos sociais, essa perspectiva se torna inadequada para trabalhar com movimentos que abrangem uma multiplicidade de causas, criando-se o paradigma dos "novos movimentos sociais" (Gohn, 2012, p.121), que engloba as reivindicações pacifistas dos anos 1970, o feminismo, a luta pelos direitos civis, o ambientalismo, entre outros. Gohn (2012) aponta que, com o processo de globalização, ocorrem transformações no cenário político, tais como a reforma do Estado e a ascensão de políticas neoliberais, que levaram a um movimento de institucionalização das demandas sociais, modificando as formas de atuação dos movimentos - inclusive com o surgimento do terceiro setor -, que passam a atuar dentro das instituições participativas do Estado. Entretanto, a estratégia de institucionalizar os conflitos sociais como resposta às demandas dos movimentos sociais não conseguiu atender aos problemas existentes, favorecendo a busca de caminhos de ação alternativos, principalmente pelo uso das TICs e pela articulação em rede dos movimentos sociais.

Por meio do uso das TICs, o ativismo das entidades da sociedade civil ganhou novos contornos e formas de atuação. A internet cria uma conjuntura capaz de tecer novas formas de relações sociais, novos fomentos de capital social, novos meios de ativismo, mecanismos de e-participação e criativas estratégias de ação, de maneira a promover o empoderamento da sociedade civil. Sandor Vegh (citado em Cavalcante, 2010) identifica três modalidades de ciberativismo: (a) awareness/advocacy (conscientização/apoio) - emprego da internet como meio alternativo à mídia tradicional de notícia e pesquisa, formando uma rede de distribuição de informações; (b) organização e mobilização - chamada para uma ação off-line (mobilização usando os recursos de comunicação da internet), que pode ser mais eficiente on-line (envio de correspondência para autoridades) e a chamada para uma ação que só pode ser realizada on-line (envio de spams para derrubar os servidores); e (c) ação e reação - ativismo hacker que atua invadindo e congestionando sites.

Araújo e Freitas (2012), ao estudar o ativismo virtual do site WikiLeaks, identificaram a polissemia do conceito de webativismo (ou ciberativismo), e acabaram por utilizar uma definição, a mesma adotada neste texto, que agrupa as diferentes perspectivas teóricas dos autores que estudam o fenômeno (Manuel Castells, David Ugarte, Sérgio Amadeu da Silveira, Henrique Antoun, Fabio Malini, Samira Marzochi):

Consideramos ciberativismo o conjunto de práticas realizadas em redes cibernéticas, com o objetivo de ampliar os significados sociais por meio da circulação na rede de discursos e de ferramentas capazes de colaborar na defesa de causas específicas. Trata-se de uma nova cultura de ligação com os assuntos de uma cidadania em contexto global (Araújo, Freitas, 2012, p.114).

Dentro dessa perspectiva ampliada de webativismo, o ativismo na internet pode empregar diferentes formas em suas estratégias de planejamento, articulação e ação, assim como proporcionar a formação de novos movimentos sociais e novas formas de ativismo (Machado, 2007). Dessa forma, o espaço rizomático da web oferece uma multiplicidade de 
oportunidades para as ações de movimentos sociais, ONGs e outras associações da sociedade civil, que podem utilizar o ciberespaço para desenvolver estratégias de comunicação (agenda de ações, legislações, notícias etc.), propiciar interação entre os membros de sua rede e de outras redes (uso de e-mail, fóruns, redes sociais, chats etc.), oferecer serviços aos usuários, ampliar a captação de recursos, promover mobilizações (off-line e/ou on-line), ampliar a conscientização e a filiação, criar petições on-line e outras formas de participação por meio dos recursos das TICs.

O rápido crescimento da web também possibilita a criação de uma esfera pública alternativa (Moraes, 2000), pela qual os movimentos sociais e entidades da sociedade civil podem expressar seus frames e suas identidades sem a mediação da mídia tradicional, criando uma agenda pública alternativa e mais aberta para a intervenção social. O ciberespaço se transforma em um novo espaço estratégico de comunicação e disputa simbólica que, devido às suas características técnicas, permite que as organizações da sociedade civil desenvolvam estratégias de visibilidade, que ampliem sua capacidade de articulação, organização e mobilização política.

Contudo, é importante destacar que a expansão da internet está associada a um processo de convergência digital das informações. As informações que circulam no ciberespaço estão associadas aos conteúdos produzidos nos meios de comunicação tradicionais, formando o que Jenkins (2008, p.50) chama de "cultura da convergência". A internet amplia o sistema convencional de circulação e de produção da informação. Dessa forma, as organizações da sociedade civil, em suas estratégias de comunicação e ação, acabam utilizando a web também para pautar a mídia tradicional e circular conteúdos que atendam a seus interesses, aumentando a visibilidade e credibilidade de suas ações.

Atuando dentro do paradigma de redes, as práticas ativistas na web criam um novo sujeito coletivo, mais complexo, capaz de produzir ações que podem criar uma nova dinâmica nas estruturas de poder e democratizar as políticas públicas, abrindo mais espaço para a atuação da sociedade civil (Egler, jan.-abr. 2010). Nesse contexto, o ativismo on-line passa a formar redes de solidariedade e cooperação atuando em escala global, proporcionando novas relações sociais e possibilidades políticas de intervenção da sociedade na esfera pública (Kahn, Kellner, 2004).

A partir do conceito de redes tecnossociais - relação de atores que utilizam as redes como suporte telemático - Egler (jan.-abr. 2010) defende que essa nova forma de organização política e social pode ser um instrumento de inovação nas relações cívicas. As TICs, por sua estrutura e características técnicas, ampliam a capacidade de participação social e possibilitam novas formas de organização das redes sociais, da articulação política e da ação coletiva. Com isso, as tecnologias permitem a criação de uma nova forma de interação entre o Estado e a sociedade civil, horizontal e direta, que potencializa a capacidade de ação para a resolução de problemas sociais, ampliam a cobrança do poder público e a pressão sobre os agentes políticos, e possibilitam outras formas de atividade política.

A maioria dos estudos sobre webativismo no Brasil é voltada para a análise da utilização de ferramentas pelos ciberativistas e a avaliação de ações específicas desenvolvidas pelos militantes (Araújo, 2011), quase inexistindo pesquisas voltadas para a avaliação do uso da rede 
como ferramenta para a promoção da participação cidadã no processo de desenvolvimento de políticas públicas, interagindo (em parceria ou por pressão) por meio dos mecanismos comunicacionais da web com o Estado. Esses tipos de abordagens revelam uma visão restrita do ativismo on-line, encarado somente como forma de resistência, sem considerar a heterogeneidade da sociedade civil e as inovadoras formas de atuação, potencialmente democráticas, que as TICs possibilitam para as organizações civis. Essas ações expressam e afirmam identidades, valores e interesses sem a necessidade de intermediação; além disso, realizam debates públicos que preparam os indivíduos para o engajamento político, mobilizam e conscientizam as pessoas para as pautas dos grupos e contribuem para a criação de ferramentas de fiscalização e transparência do poder público, conforme argumenta Maia (2007).

Por outro lado, a bibliografia sobre a participação da sociedade por meio das novas tecnologias é direcionada para estudar práticas de e-gov (governo eletrônico), nas quais o governo desenvolve um desenho institucional (top-down) que possibilita a participação cidadã por meio do ciberespaço (Macintosh, Whyte, 2008; Meijer, Burger, Ebbers, 2009).

Apesar de cada vez mais as organizações da sociedade civil e os movimentos sociais utilizarem os recursos das TICs em suas práticas políticas (institucionais e não institucionais) na defesa de seus interesses, como ocorre nos casos analisados nessa pesquisa, pouca atenção é dada a essas ações, que utilizam os dispositivos de comunicação da internet para participar do processo de tomada de decisão política (policy decision-making) e influenciá-lo tornando o processo político mais participativo e democrático (Avritzer, 2008) ou eficiente e legítimo (Perez, 2006), representando uma importante lacuna dentro das ciências sociais.

\section{E-participação e políticas públicas: descrição e mensuração do Índice de Participação Política e Influência}

A mudança no perfil de atuação da sociedade civil, com o uso das TICs, abre caminho para que as entidades civis tenham participação mais ativa na vida pública. Os mecanismos de comunicação interativos e colaborativos da internet criam condições para que esses grupos da sociedade desenvolvam novas atividades políticas, principalmente no exercício de influência sobre políticas públicas setoriais. Com o objetivo de estudar essa prática, foi desenvolvida uma ferramenta metodológica de mensuração dessa relação: o Índice de Participação Política e Influência (IPPI), que visa avaliar como a sociedade civil, dentro de sua heterogeneidade, está se apropriando dos recursos da internet para promover a participação cidadã e conseguir influenciar o processo de desenvolvimento de políticas públicas em pelo menos alguma etapa do ciclo (Araújo, Penteado, Santos, 2014).

A avaliação da participação (e-participação) e influência sobre políticas públicas envolve uma série de fatores complexos, que representam dificuldades metodológicas. Há a necessidade de uma múltipla dimensionalidade que abarque conhecimentos teóricos de diferentes campos de conhecimento como ciência política, políticas públicas, comunicação política, sociologia, ciência da informação e áreas de pesquisa como e-participação, ciberativismo, movimentos sociais etc. 
O Índice de Participação Política e Influência da sociedade civil no ciclo de políticas públicas possui cinco dimensões analíticas criadas com base na revisão da literatura sobre o tema: Usos e recursos da internet (D1); Atores e capital social (D2); E-participação e estratégias de mobilização (D3); Desdobramento da ação e relação com as políticas públicas (D4) e; Repercussão na mídia tradicional (D5).

O desenvolvimento dessas categorias procura analisar a capilaridade das relações entre sociedade civil e Estado por meio dos usos da internet tanto na mediação e articulação quanto na repercussão das ações desenvolvidas pelos diferentes grupos. As categorias foram pensadas com o intuito de dar forma aos distintos níveis de participação política on-line e off-line e às diferentes estratégias adotadas pelos grupos com o intuito de influenciar de alguma forma o processo de desenvolvimento de políticas.

Nesse sentido, as cinco dimensões citadas visam integrar esses diferentes referenciais teóricos (brevemente expostos no artigo) e metodológicos em uma ferramenta de análise e avaliação prática que facilite o desenvolvimento de pesquisas sobre o tema. Elas procuram também verificar o potencial de influência exercido por grupos da sociedade civil, por meio do ativismo digital e sua ingerência sobre o ciclo de políticas públicas, evidenciando um novo modus operandi.

O Quadro 1, com a descrição das dimensões de análise do IPPI, apresenta os critérios de mensuração de cada uma delas, que variam em uma escala de 0 a 5, conforme detalhado abaixo:

Quadro 1: Dimensões do IPPI

\begin{tabular}{|c|c|c|}
\hline Dimensões do IPPI & Descrição & Mensuração \\
\hline $\begin{array}{l}\text { 1. Uso dos recursos } \\
\text { da internet/TICs }\end{array}$ & $\begin{array}{l}\text { Identificação e avaliação } \\
\text { dos dispositivos } \\
\text { comunicacionais que o } \\
\text { grupo/coletivo utiliza em } \\
\text { uma ação ativista }\end{array}$ & $\begin{array}{l}0 \text { - não utiliza recursos da internet } \\
1 \text { - apenas utiliza um site } \\
2 \text { - utiliza além do site, redes sociais, Youtube } \\
3 \text { - o site oferece ferramentas, aplicativos e dispositivos para } \\
\text { a mobilização e debate sobre temas correlacionados a PPs } \\
4 \text { - o site e redes sociais oferecem ferramentas, aplicativos } \\
\text { e dispositivos para a mobilização e debate sobre temas } \\
\text { correlacionados a PPs } \\
5 \text { - os usuários podem participar da produção de propostas e } \\
\text { ações do grupo ciberativista }\end{array}$ \\
\hline $\begin{array}{l}\text { 2. Atores envolvidos } \\
\text { e capital social }\end{array}$ & $\begin{array}{l}\text { Identificação e } \\
\text { classificação dos atores } \\
\text { envolvidos quanto ao } \\
\text { seu capital social para a } \\
\text { mobilização de recursos } \\
\text { financeiros e mobilização } \\
\text { de pessoas }\end{array}$ & $\begin{array}{l}0 \text { - os atores envolvidos não possuem ligações com outros } \\
\text { grupos ou instituições } \\
1 \text { - os atores envolvidos pertencem a uma rede de } \\
\text { movimentos sociais locais/regionais } \\
2 \text { - os atores envolvidos pertencem a uma rede de } \\
\text { movimentos sociais nacionais } \\
3 \text { - os atores envolvidos pertencem a uma rede de } \\
\text { movimentos sociais internacionais } \\
4 \text { - os atores envolvidos pertencem a uma rede de } \\
\text { movimentos sociais e possuem vínculos com instituições } \\
\text { públicas } \\
5 \text { - os atores envolvidos pertencem a uma rede de } \\
\text { movimentos sociais, possuem vínculos com instituições } \\
\text { públicas e atuam dentro dos mecanismos de representação } \\
\text { política }\end{array}$ \\
\hline
\end{tabular}




\section{Quadro 1 (cont.): Dimensões do IPPI}

\begin{tabular}{|c|c|c|}
\hline $\begin{array}{l}\text { 3. Tipos de } \\
\text { webativismo e } \\
\text { plano estratégico } \\
\text { de ação }\end{array}$ & $\begin{array}{l}\text { Identificação e } \\
\text { classificação das } \\
\text { formas de webativismo } \\
\text { (e-participação, com } \\
\text { base nas categorias } \\
\text { desenvolvidas por } \\
\text { Tamborius et al., } 2007 \text { e } \\
\text { Araújo, Penteado, Santos, } \\
\text { 2013) e uso dos recursos } \\
\text { do ciberespaço para a } \\
\text { mobilização }\end{array}$ & $\begin{array}{l}\text { 0 - e-informação: há apenas informação para cidadãos; não } \\
\text { há interatividade, a página não encoraja o engajamento da } \\
\text { sociedade na causa em questão } \\
1 \text { - e-consulta: possibilita o recolhimento de informações } \\
\text { do público em geral; as ações utilizam ferramentas básicas } \\
\text { de comunicação como envio de e-mails e enquetes; há } \\
\text { o encorajamento da mobilização apenas por meio de } \\
\text { informações publicadas na página } \\
2 \text { - e-mobilização: há ação de estímulo e convocação na } \\
\text { defesa de valores e ideias; uso de eventos do Facebook e } \\
\text { outras formas de interação e mobilização nas redes sociais } \\
3 \text { - e-engajamento: alem das características acima, os } \\
\text { cidadãos defendem suas ideias e valores em detrimento } \\
\text { de outras; presença de convocação em cascata e uso de } \\
\text { torpedos, além do uso das redes sociais } \\
4 \text { - e-deliberação: a ação auxilia na resolução de impasses, } \\
\text { tomadas de decisão a partir de discussão e debate entre } \\
\text { atores políticos; a mobilização ocorre por meio de uma } \\
\text { somatória de estratégias que envolvem o uso das TICs e, em } \\
\text { alguns casos, o uso dos meios de comunicação de massa } \\
5 \text { - e-empoderamento: há transferência de influência, } \\
\text { controle, proposição e formulação de políticas a partir } \\
\text { dos desejos e anseios dos cidadãos; ocorrem ações de } \\
\text { mobilização com utilização das ferramentas tecnológicas e } \\
\text { meios de comunicação de massa, além do desenvolvimento } \\
\text { de ações off-line de conscientização e promoção do } \\
\text { engajamento social }\end{array}$ \\
\hline $\begin{array}{l}\text { 4. Desdobramento } \\
\text { da ação e relação } \\
\text { com PPs }\end{array}$ & $\begin{array}{l}\text { Verificar se após a } \\
\text { realização de uma ação } \\
\text { ou mobilização houve um } \\
\text { desdobramento político: } \\
\text { proposta de uma política } \\
\text { pública, influência na } \\
\text { formação da agenda etc. }\end{array}$ & $\begin{array}{l}0 \text { - as ações não são consideradas pelo poder público } \\
1 \text { - as ações são incorporadas a discursos, mas não são } \\
\text { incluídas emprojetos ou programas de governo } \\
2 \text { - as ações são incorporadas a projetos novos ou } \\
\text { influenciam a revisão e avaliação de agendas do governo } \\
3 \text { - as ações são determinantes para a formação da agenda } \\
\text { de governo e influenciam novos projetos e planos de metas } \\
\text { para a gestão } \\
4 \text { - as ações implicam a elaboração própria de políticas que } \\
\text { são incorporadas pelos governos. O governo mantém para si } \\
\text { a tarefa de implementação e avaliação } \\
5 \text { - as ações implicam a elaboração de diretrizes e projetos } \\
\text { por parte da sociedade civil que são incorporadas pelo } \\
\text { governo. O Estado permite o envolvimento da sociedade civil } \\
\text { também na implementação e avaliação do projeto }\end{array}$ \\
\hline $\begin{array}{l}\text { 5. Repercussão na } \\
\text { mídia }\end{array}$ & $\begin{array}{l}\text { Identificar se a ação } \\
\text { ou mobilização teve } \\
\text { repercussão nas mídias } \\
\text { tradicionais e dentro do } \\
\text { ciberespaço }\end{array}$ & $\begin{array}{l}0 \text { - não há repercussão na mídia tradicional } \\
1 \text { - ocorrem referências indiretas da ação em jornais e/ou } \\
\text { revistas impressas de bairro e/ou de circulação local } \\
2 \text { - ocorrem referências diretas à ação em jornais e/ou } \\
\text { revistas impressas de bairro e/ou de circulação local } \\
3 \text { - ocorrem referências indiretas à ação em meios de } \\
\text { comunicação eletrônicos tradicionais (rádio e TV) com ou } \\
\text { sem referências a periódicos impressos } \\
4 \text { - ocorrem referência direta à ação em meios de } \\
\text { comunicação eletrônicos tradicionais (rádio e TV) com ou } \\
\text { sem referências a periódicos impressos } \\
5 \text { - as ações são noticiadas e/ou comentadas de forma direta } \\
\text { por meios eletrônicos e impressos com enquadramento } \\
\text { propositivo, chamando a atenção do poder público }\end{array}$ \\
\hline
\end{tabular}

Fonte: Elaboração dos autores, 2014. 
No sentido de contribuir com o estudo da atuação das diferentes organizações, coletivos e movimentos sociais que utilizam o ciberespaço em suas propostas, foi realizada uma análise de algumas ações, com o intuito de caracterizá-las e avaliar as estratégias de mobilização adotadas.

Essa nova prática de atuação, até por sua natureza horizontalizada, apresenta uma dificuldade metodológica. Novas ações surgem rapidamente, ocorrem alterações de nomenclatura, desativações e parcerias. Não é possível, portanto, obter um mapa fixo do webativismo. Para este trabalho, primeiramente foi feito um levantamento de ações que se apropriaram das ferramentas da internet como meio de concretização de seus objetivos. Esse levantamento inicial foi realizado pelo grupo de pesquisadores a partir da análise de redes de movimentos e grupos sociais ativos na cidade de São Paulo em 2013. Em seguida, essas ações foram filtradas a partir dos seguintes critérios: (a) que a ação estivesse ativa a partir de 2011; (b) que se tivesse usado a internet como estratégia em alguma etapa da ação; (c) que tivesse sido uma ação política exógena; (d) que tivesse exercido algum tipo de influência na cidade de São Paulo. Após a aplicação dos filtros, foi constituído um banco de dados com 145 ações, que foram caracterizadas com uma breve descrição. Dessas ações foram selecionadas para análise as 46 mais significativas, isto é, ações de webativismo que tiveram alguma pontuação dentro do índice exposto anteriormente.

Essas 46 ações foram submetidas à ferramenta metodológica do IPPI, que permitiu uma hierarquização das ações, uma análise comparativa e uma melhor avaliação das estratégias de ação (e-participação) adotadas pelos grupos em questão. Essa amostra qualificada foi avaliada a partir das cinco dimensões de análise, conforme descritas no Quadro 1. A seguir, são apresentados os resultados da análise.

Quadro 2: Avaliação das ações de webativismo

\begin{tabular}{|l|l|l|l|l|l|}
\hline Ações & D1 & D2 & D3 & D4 & D5 \\
\hline Ação Educativa & 3 & 3 & 3 & 2 & 2 \\
\hline Acãochego & 3 & 2 & 3 & 1 & 0 \\
\hline Campanha Banda Larga & 4 & 5 & 2 & 4 & 2 \\
\hline Ciclocidade & 4 & 3 & 2 & 2 & 2 \\
\hline Cidades para Pessoas & 4 & 2 & 2 & 2 & 2 \\
\hline Coletivo Digital & 4 & 3 & 4 & 2 & 0 \\
\hline Movimento Eu Agradeço a um Professor & 3 & 1 & 2 & 0 & 1 \\
\hline Movimento Passe Livre & 4 & 3 & 4 & 5 & 5 \\
\hline Movimento Tarifa Zero & 4 & 3 & 4 & 4 & 4 \\
\hline Pimp My Carroça & 4 & 2 & 3 & 2 & 0 \\
\hline Movimento de Trabalhadores da Cultura & 5 & 4 & 5 & 5 & 0 \\
\hline Cultura Atravessa & 3 & 5 & 5 & 4 & 2 \\
\hline Coletivo Fora do Eixo & 5 & 4 & 5 & 3 & 2 \\
\hline Movimento Contra a Corrupção & 3 & 1 & 1 & 2 & 1 \\
\hline Fórum CBT & 2 & 3 & 4 & 4 & 3 \\
\hline Movimento dos Trabalhadores Sem Teto & 2 & 3 & 3 & 2 & 3 \\
\hline Marcha das Vadias & 5 & 3 & 2 & 3 & 3 \\
\hline Espalhe a Verdade & 2 & 1 & 1 & 0 & 0 \\
\hline Coletivo Nasa & 2 & 1 & 1 & 1 & 1 \\
\hline Comissão da Verdade & 3 & 3 & 2 & 4 & 3 \\
\hline
\end{tabular}


Quadro 2 (cont.): Avaliação das ações de webativismo

\begin{tabular}{|l|c|c|c|c|c|}
\hline Ações & D1 & D2 & D3 & D4 & D5 \\
\hline Contra o Genocídio do Povo Negro & 3 & 3 & 3 & 1 & 1 \\
\hline Contra os Corruptos do Mensalão & 3 & 1 & 1 & 0 & 0 \\
\hline Cultura Indígena em Rede & 4 & 4 & 2 & 2 & 2 \\
\hline Cultura Verde & 4 & 4 & 2 & 4 & 2 \\
\hline Curativos Urbanos & 4 & 4 & 3 & 0 & 2 \\
\hline Coletivo DAR & 5 & 4 & 2 & 1 & 1 \\
\hline Democracia na PUC & 1 & 3 & 3 & 3 & 3 \\
\hline Mídia Ninja & 4 & 4 & 2 & 0 & 2 \\
\hline OCC - Organização de Combate à Corrupção & 4 & 3 & 3 & 1 & 2 \\
\hline Revoltados On-line & 4 & 3 & 3 & 1 & 2 \\
\hline Pós-TV & 4 & 4 & 2 & 0 & 0 \\
\hline Nas Ruas Contra a Corrupção & 3 & 3 & 3 & 2 & 1 \\
\hline Dia do Basta & 4 & 3 & 4 & 1 & 4 \\
\hline Mães de Maio & 3 & 4 & 3 & 0 & 2 \\
\hline Movimento Direito para Quem & 1 & 3 & 1 & 0 & 0 \\
\hline OSP - Organização dos Sem Partido & 1 & 2 & 2 & 0 & 0 \\
\hline Global Noise \#Panelaço A Cidade é Nossa! & 2 & 2 & 4 & 4 & 2 \\
\hline Experimenta SP & 2 & 3 & 4 & 3 & 2 \\
\hline Coletivo 28 de Julho & 1 & 3 & 2 & 0 & 0 \\
\hline Abracci & 2 & 4 & 4 & 3 & 2 \\
\hline Ação Cidadania & 3 & 5 & 5 & 3 & 5 \\
\hline AnonymousBR & 3 & 3 & 4 & 2 & 3 \\
\hline Ativismo de Sofá & 1 & 1 & 2 & 0 & 0 \\
\hline Ativismo Virtual & 5 & 5 & 5 & 4 & 4 \\
\hline Atletas pela Cidadania & 2 & 1 & 2 & 4 & 3 \\
\hline Cine na Praça & & 1 & 2 & 0 & 0 \\
\hline
\end{tabular}

Fonte: Elaboração dos autores, 2014.

Legenda:

D1) Uso dos recursos da internet/TICs

D2) Atores envolvidos e capital social

D3) Tipos de webativismo

D4) Desdobramento da ação e relação com o processo de desenvolvimento de políticas públicas

D5) Repercussão na mídia tradicional

O Quadro 2 apresenta todas as ações que foram analisadas e as respectivas notas atribuídas a cada uma das cinco dimensões. ${ }^{3}$ No entanto, é preciso registrar o caráter dinâmico do objeto de estudo, o que pode gerar algumas discordâncias. Por exemplo, a Mídia Ninja, o Movimento dos Trabalhadores Sem Teto e o Coletivo Fora do Eixo receberam recentemente grande atenção da mídia tradicional, o que seria suficiente para elevação de suas notas na dimensão 5 . No entanto, como a classificação foi realizada anteriormente às notícias veiculadas sobre esses coletivos, ${ }^{4}$ não foi possível a readequação das notas. O Quadro 2 permite uma visualização de certa homogeneidade. De forma geral, as avaliações recebidas em cada uma das dimensões de uma ação são próximas umas das outras, o que indica uma unidade estratégica de cada ação ou, quando ocorre uma discrepância entre as dimensões, é possível constatar especificidades da ação. O agrupamento das dimensões permite uma observação da multidimensionalidade que envolve essa forma de atuação e uma avaliação contextual. O Gráfico 1 apresenta a consolidação da pontuação e a comparação das ações. 
Gráfico 1: Avaliação da participação política e influência (5 dimensões)

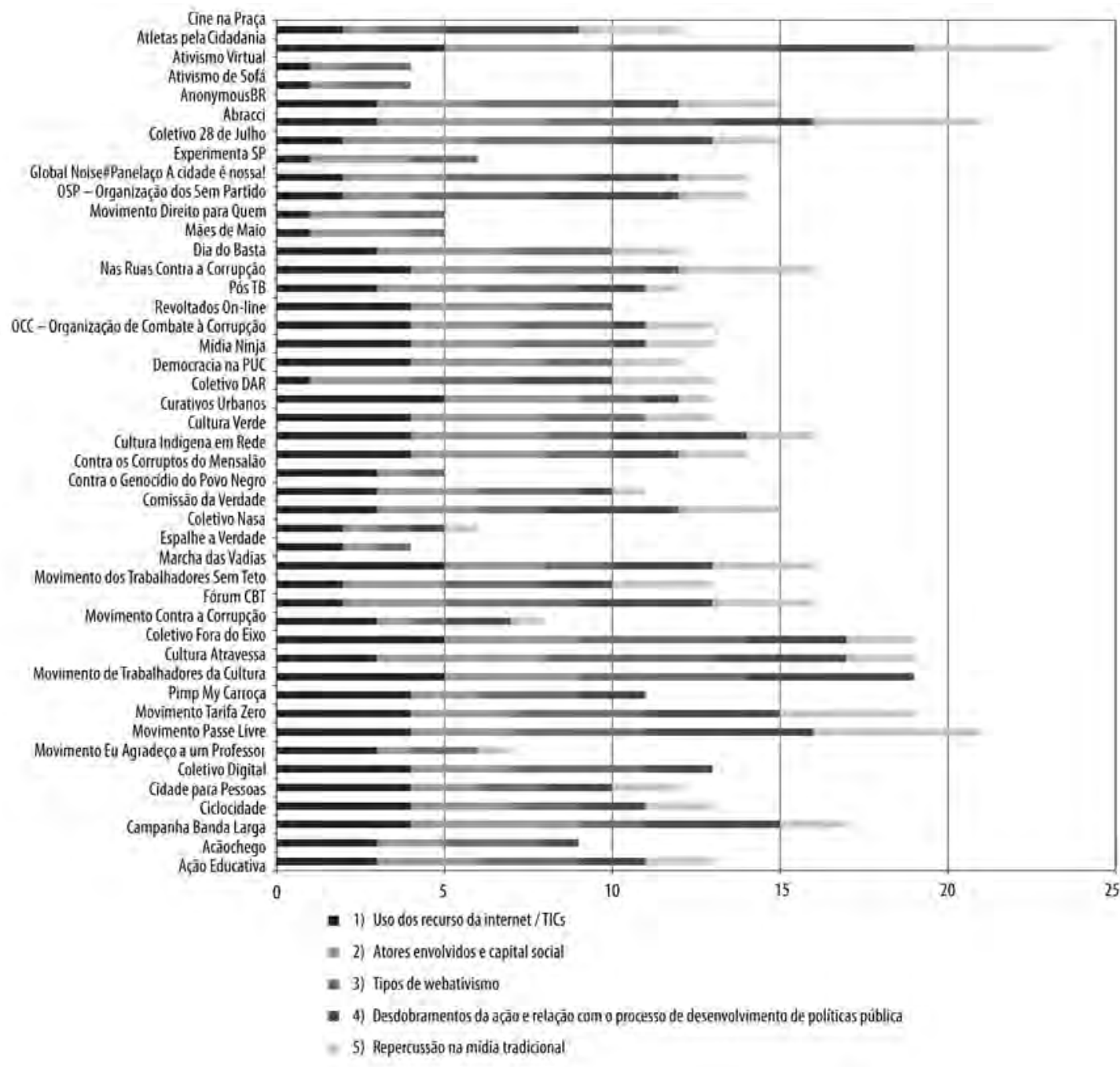

Fonte: Elaboração dos autores, 2014.

Para efeito de comparação, o Gráfico 1 apresenta as notas das cinco dimensões agrupadas. Embora não seja possível ainda atribuir pesos para cada uma das dimensões, o gráfico permite verificar a somatória das avaliações atribuídas a cada ação, hierarquizando-as.

As ações que apresentaram maior avaliação foram: Atletas pela Cidadania, Ação Cidadania, Movimento Passe Livre, Movimento Tarifa Zero, Cultura Atravessa, Movimento de Trabalhadores da Cultura, Coletivo Fora do Eixo. Essas ações foram caracterizadas por sua inventividade e dinâmica de ação, agrupando um número significativo de estratégias, tais como campanhas de comunicação envolvendo pessoas públicas, panfletagem e afixação de cartazes, uso de mensagens SMS, convocação em cascata e presença na mídia tradicional. O uso de diferentes estratégias é seguido de uma atualização constante das informações na internet, demonstrando dinamismo e envolvimento. 
Essa lista de ações envolve movimentos e coletivos com elevado grau de organização e com importantes conexões com os mecanismos participativos do Estado e grande capacidade de mobilização de recursos para suas atividades, seja por meio de doações e parcerias com entidades privadas (Atletas pela Cidadania e Ação Cidadania) ou por acesso a editais públicos (Cultura Atravessa, Movimento de Trabalhadores da Cultura e Coletivo Fora do Eixo). Os movimentos Passe Livre e Tarifa Zero apresentam perfil diferenciado, com caráter mais contestatório. O resultado das jornadas de junho de 2013, que tiveram início a partir dos protestos contra o aumento da tarifa em São Paulo, acabou por interferir na sua pontuação (principalmente nas dimensões 2, 4 e 5), evidenciando a complexidade que envolve o fenômeno em estudo.

Vale destacar, ainda, que ações de webativismo envolvendo os temas de mobilidade urbana (Movimento Passe Livre e Movimento Tarifa Zero), cidadania (Atletas pela Cidadania e Ação Cidadania) e cultura (Cultura Atravessa, Movimento de Trabalhadores da Cultura, Coletivo Fora do Eixo) tiveram uma boa classificação.

As ações que receberam as piores avaliações: Ativismo Virtual, Ativismo de Sofá, Organização dos Sem Partido, Movimento Direito para Quem, Contra os Corruptos do Mensalão e Espalhe a Verdade. Tais iniciativas apenas usaram o Facebook para veiculação de informação, não apresentaram qualquer estratégia de mobilização e envolvimento (engajamento). Esse tipo de ativismo se caracteriza por ser mais um espaço para expressão de indignação e protesto contra o sistema político, partidos e políticas públicas específicas, sem apresentar um perfil propositivo ou de construção de alternativas políticas. As demais ações possuem estratégias de mobilização variadas.

Os resultados permitem observar que as ações com melhor performance, no geral, possuem uma estrutura de ação política que não está limitada ao ciberespaço, existe uma combinação efetiva de ações on-line (em alguns casos criativas e inovadoras) e off-line, o que de certa forma mostra o limite de alcance de grande parte de ações de webativismo que se limitam ao espaço da rede mundial de computadores.

Para a identificação das estratégias adotadas, apresentamos o Gráfico 2, que sistematiza essas práticas e permite verificar que a maioria das ações estudadas utiliza como estratégia de mobilização a criação de eventos no Facebook. Isso corresponde a 27,2\% das estratégias adotadas. Esse resultado pode ser explicado pela grande popularidade da rede social de internet entre os usuários brasileiros. Em seguida, destacam-se a circulação de informações nas redes sociais $(12,8 \%)$ e a produção e divulgação de conteúdos $(11,2 \%)$. Vale salientar a criação de eventos artísticos, culturais e educacionais, tais como seminários, palestras de formação e performances diversas como meio criativo de mobilização e engajamento, que em muitos casos estão associados a coletivos que atuam na área de cultura ou marcam o ativismo de performance (Mesquita, 2008). Essa estratégia foi identificada em oito ações $(6,4 \%)$. A categoria "outros" incluiu estratégias que foram verificadas em diferentes ações, são elas: conferências e debates on-line; uso de mensagens SMS; crowdfunding (financiamento colaborativo); divulgação em mídia tradicional; transmissão ao vivo pela internet (streaming); enquetes; cadastro de militantes; divulgação junto a entidades relacionadas ao tema; hackeamento de sites; e envolvimento de pessoas públicas. Essas estratégias, embora tenham sido pouco utilizadas, podem exercer um alto grau de influência, especialmente as que envolvem elementos 
Gráfico 2: Estratégias de ação e mobilização

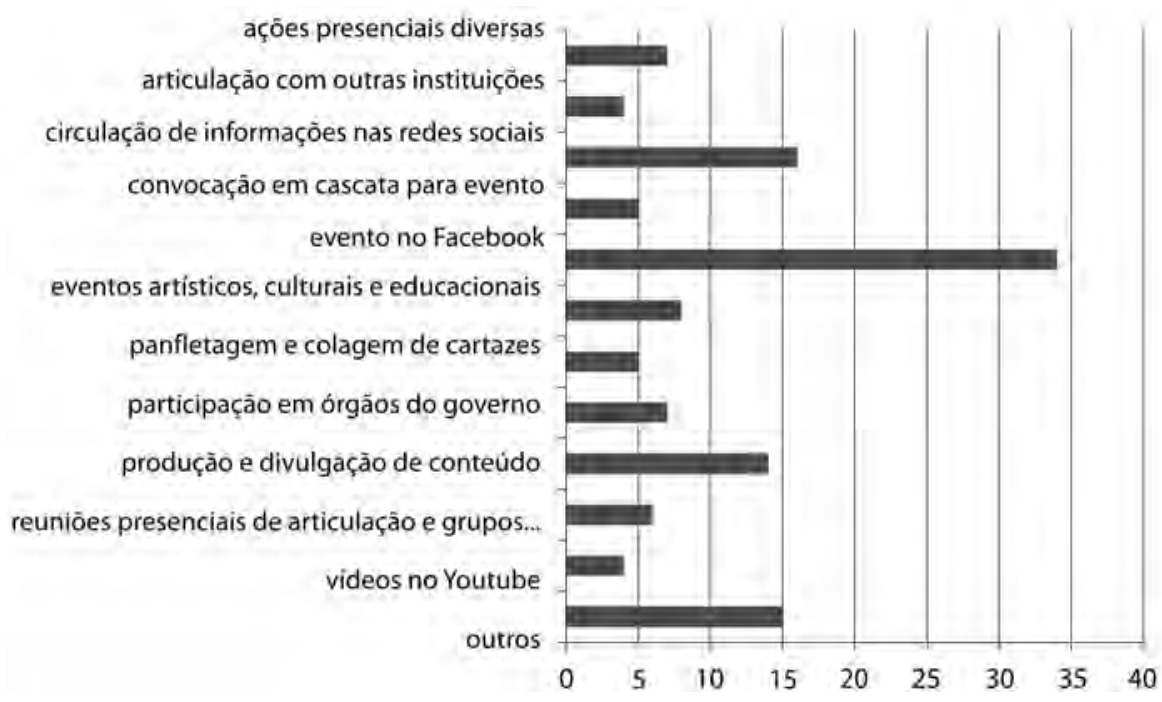

Fonte: Elaboração dos autores, 2014.

simbólicos, tais como a associação da ação a pessoas públicas, como é o caso do Atletas pela Cidadania, e o hackeamento de sites realizado pelo AnonymousBR. Além disso, foi possível notar o elevado poder de mobilização da circulação de vídeos de registro realizados pela população e a convocação em cascata, capaz de fazer chegar o convite para um evento a centenas de milhares de usuários do Facebook. O uso de mensagens SMS também é bastante eficaz, pois confere credibilidade às convocações.

O Gráfico 2 permite ainda verificar uma variedade de estratégias que ultrapassam o simples uso das redes sociais. Foi possível notar que as ações que ganham destaque utilizam uma somatória de estratégias. Merece ênfase o fato de que muitos dos coletivos reconhecem a necessidade de manter atividades presenciais, tais como reuniões e grupos de debate, além de panfletagem e colagem de cartazes. Alguns grupos também adotam como estratégia a participação em órgãos governamentais, tais como os conselhos municipais, e participam de editais para a obtenção de financiamentos públicos, e, com isso, podem ampliar o alcance das ações.

\section{Considerações finais}

Como discutido no artigo, os usos da internet na participação cidadã estão cada vez mais presentes nas práticas políticas brasileiras contemporâneas. As TICs têm criado novos desenhos que auxiliam o processo "de dar voz aos cidadãos". Ao tratar do tema, Jussara Borges e Othon Jambeiro (2012, p.45) afirmam:

As OSC [Organizações da Sociedade Civil], que historicamente reivindicam espaços de participação e promoção de oportunidades para a esfera civil, veem na internet uma janela para a expressão de identidades e valores. Nesse sentido, a internet propicia um canal em que os atores podem problematizar suas questões e interesses a partir de sua 
própria elaboração, questões estas que muitas vezes permaneciam ocultas pelos que controlam os meios de comunicação.

O webativismo tem demonstrado sua capacidade de debater, em espaços públicos e políticos virtuais, ideias, questões e propostas que não eram abordadas pela mídia tradicional. A ampliação dos espaços de participação é um exercício fundamental da política que contribui para a ampliação e consolidação da democracia, para além da representação política tradicional.

Ao impulsionar novas ferramentas de comunicação que fomentam a ação política, as TICs permitem à associação dos atores - organizados pelo formato de rede - redefinir suas relações de poder, eliminando intermediações e possibilitando formas diretas de ação e transformação, inclusive influenciando as políticas públicas, como identificado nessa pesquisa. Além disso, a instantaneidade e a velocidade das informações oferecem um dinâmico elemento de influência, capaz de pautar algumas ações dos representantes públicos e pautar a agenda da própria mídia tradicional para modificar sua abordagem. Este estudo analisou 46 experiências de ação política que, por intermédio dos recursos das TICs, desenvolveram um novo espaço para atuação da sociedade civil na vida pública.

Como observado, a presença das redes e o uso das TICs têm permitido ampliar o significado da participação política e suscitado novos debates acerca da democracia. De fato, o momento atual do mundo, com diversos países democráticos enfrentando discussões e protestos, coloca o debate acerca dos limites da representação ou crise da democracia representativa (Manin, 1997). As recentes movimentações pelas quais o país passou (jornadas de junho de 2013), por exemplo, demonstraram a necessidade de uma ampliação dos espaços de participação e de uma renovação dos procedimentos democráticos. Como afirma Subirats (2011, p.94):

Essa democracia renovada que buscamos, essa defesa do comum que nos impulsiona, tem na internet, como já destacamos, um cenário de potencialidades evidente. Politicamente, pois facilita notavelmente o acesso, a informação e a mobilização, evitando a transição-intermediação forçosa via partidos-instituições.

A análise das ações apresentada aqui demonstra pluralidade e inventividade nas estratégias e dá forma a um novo momento do ativismo político, que combina ações de contestação e pressão sobre o Estado, a busca de formação de parcerias ou, então, um repositório para expressão da revolta contra o sistema político em geral.

Isso corresponde ao estágio de desenvolvimento tecnológico em que nos encontramos e ao grau de racionalidade que atingimos. Segundo Milton Santos (1996), vivemos em um meio técnico-científico-informacional que corresponde ao grau de desenvolvimento tecnológico de nossa época e todas as suas implicações. Esse meio indica uma nova relação espaçotemporal que está em sintonia com o atual estágio de desenvolvimento do mundo do trabalho e da globalização. É possível extrair dessa realidade, pelo menos, duas informações importantes. A primeira é que as presenças da tecnologia e da racionalização conduziram os indivíduos a um insulamento provocado pela aceleração do tempo e pelo totalitarismo do trabalho. Isso gerou um longo processo de despolitização e enfraquecimentos dos espaços tradicionais de participação, tais como os sindicatos e partidos políticos.

A segunda informação que decorre dessa realidade é que a presença de tecnologias altera tanto o cotidiano das instituições quanto dos cidadãos. Assim, se não existe tempo 
durante o dia para que o cidadão dedique à política, uma vez que o mundo do trabalho o ocupa, a presença das TICs permite novas formas de articulação e iniciativas de mobilização. A profissionalização da política, que ganhou forma no institucionalismo e na própria democracia representativa, compreende o modelo top-down de formulação de políticas. O que tem sido visto nos últimos anos é a demonstração de que a presença das tecnologias, que sempre foram usadas para o aperfeiçoamento da racionalidade de Estado, passou agora a abrir novos espaços de participação.

A CF/88 já previa esses espaços, mas no momento em que foi produzida não havia a tecnologia hoje disponível. A participação e o engajamento na política dependiam da participação presencial. Passados mais de 25 anos, a socialização das tecnologias trouxe um novo contexto e permitiu o preenchimento de alguns desses espaços previstos na $\mathrm{CF} / 88$, além da criação de outros. A avaliação das experiências descritas aqui ajuda a melhorar a compreensão do fenômeno da participação e desse novo contexto democrático.

O trabalho pretendeu contribuir com a mensuração e interpretação das transformações dos modos de atuação da sociedade civil, por meio do uso do IPPI, que permitiu hierarquizar e comparar ações que se apropriam da internet de alguma forma para influenciar o processo de desenvolvimento de políticas públicas. O IPPI pode contribuir para o conhecimento dos potenciais de influência das ações, fornecendo pistas para a nossa compreensão a respeito do complexo fenômeno do webativismo. Por exemplo, o uso do Facebook, que, desde a aplicação do IPPI até os dias atuais, tem crescido como ferramenta de articulação e mobilização, assim como o uso de outras redes sociais. ${ }^{5}$

O conhecimento desse potencial de influência auxilia o entendimento das novas relações entre governantes e governados no atual estágio de desenvolvimento da democracia e da tecnologia. O empoderamento do cidadão corresponde a uma nova fase de um longo processo de amadurecimento, tal como afirma Subirats (2011, p.103):

A proposta de uma outra democracia, a proposta de uma democracia do comum, aqui parcialmente exposta, mas presente em muitos lugares e experiências em todo o mundo, está ganhando terreno e está presente na crescente mobilização social em todo o mundo. Não há dúvidas de que continuaremos falando dela e, melhor ainda, que continuaremos a experienciá-la.

Ao presenciar a intensificação dos protestos de rua e o crescimento em progressão geométrica das ações que se valem da internet como meio de organização, vemos o despontar de uma "multidão" (Hardt, Negri, 2005, p.143).

A "multidão" é fragmentada, pluralista e se articula mediante redes. Não tem coesão interna, é colaborativa e, principalmente, criativa e resistente. A sua resistência passa, necessariamente, pela comunicação digital. Essa é uma realidade nova que o mundo vive e que ainda não foi compreendida, pois o webativismo tem sido interpretado a partir de velhos modelos. Procuram-se lideranças e causas específicas, mas o modelo de participação não tem sido colocado em pauta. As TICs permitiram ao cidadão ampliar a participação sem sacrificar o mundo do trabalho; por outro lado, também podem insular o cidadão na defesa de interesses particulares ou fomentar o discurso de ódio, xenofobismo, preconceitos, como pode ser visto nas redes sociais de internet. A militância político-partidária brasileira 
atual pode ser um bom exemplo de espaço para antagonização e desqualificação do outro, por motivos não racionais, uma vez que esses grupos promovem discussões políticas maniqueístas e simples, muitas vezes desprovidas de argumentação racional.

A articulação em rede garante à população uma pluralidade de perspectivas sobre os mais diversos fatos e, principalmente, a uma velocidade que a mídia tradicional não consegue acompanhar e modular. O resultado disso é que, com intensidade cada vez maior, as ações promovidas com o uso das TICs têm pautado a agenda da mídia tradicional e da administração pública. Esse procedimento tem sido adotado como estratégia pelos webativistas, e tem se mostrado algo bastante eficaz para chamar a atenção do poder público. Os recentes protestos contra o aumento de preço das passagens em 2013 vislumbraram o potencial das TICs como ferramenta de ação política. Como observado no Gráfico 1, alguns grupos, como Coletivo Fora do Eixo, Mídia Ninja e, mais recentemente, o Revoltados On-line, fazem uso dos recursos de internet.

Ao analisar as diferentes iniciativas de webativismo, cria-se um parâmetro de compreensão do comportamento da "multidão", o que justifica o esforço em desenvolver estudos sobre essas formas de ação política que passa pela apropriação das TICs. De acordo com Michael Hardt e Antonio Negri (2005, p.447):

Já podemos reconhecer que hoje o tempo se divide em um presente que já está morto e um futuro que já nasceu - e o abismo entre os dois vai se tornando enorme. Com o tempo algum evento haverá de nos impulsionar como uma flecha para esse futuro vivo. Será este o verdadeiro ato de amor político.

Os autores não escondem o otimismo em sua análise. A avaliação da realidade política contemporânea, realizada antes da onda de manifestações que se espalharam pelo mundo, já apontava para a possibilidade de uma nova participação política como forma de resistir à sociedade de controle. Hardt e Negri (2005, p.294) afirmam que, no contexto de globalização e neoliberalismo, "a democracia global terá de significar algo diferente do que significa democracia no contexto nacional ao longo de toda a era moderna". Isso representa o reconhecimento de que o controle por parte dos governantes, na forma plural que assume na contemporaneidade, deverá ser tratado por parte dos governados com novas estratégias, com a constituição de uma força que ultrapassa a violência física e apela para a socialização do poder simbólico.

As redes tecnossociais modificaram totalmente o cotidiano dos homens. A convergência digital faz com que os indivíduos estejam conectados o tempo todo, além de ter acesso a uma quantidade imensurável de informações. Essa realidade técnico-científica-informacional implica o reconhecimento de que a participação política compreende o entrelaçamento dos mundos on-line e off-line (conforme apontam os resultados da pesquisa apresentada, em que os melhores indicadores das organizações sociais estão associados ao uso criativo das ferramentas digitais e, principalmente, pela capacidade de conexão entre o ativismo virtual e presencial).

A opinião pública condiciona-se a essa velocidade, e, a despeito de não haver uma cultura política generalizada, a sociedade civil organizada parece ter percebido como se valer dessa realidade, fazendo com que haja a validação de propostas pelo maior número possível de pessoas mediante mecanismos diversos. Os governos têm percebido essas mudanças e têm 
procurado se adaptar, como, por exemplo, o governo federal, que criou o Plano Nacional de Participação Social, numa tentativa de incrementar a cidadania. No entanto, se a nova realidade implica um processo constante de inventividade e renovação, as estratégias de mobilização oferecem sempre novos meios de se exercer pressão, e os governantes são obrigados a responder de alguma forma a essas manifestações. Trata-se de uma realidade bastante complexa, que implica um número grande de variáveis e uma abordagem interdisciplinar.

\title{
NOTAS
}

\begin{abstract}
${ }^{1}$ Nessa e nas demais citações de textos em outros idiomas, a tradução é livre.
${ }^{2} \mathrm{O}$ caso da Islândia, com a elaboração de sua nova constituição pós-crise econômica (ponderando-se todas as suas especificidades), pode ser um bom exemplo dessa nova possibilidade política.

${ }^{3}$ A pontuação foi atribuída coletivamente pela equipe de pesquisadores após a avaliação de cada uma das ações a partir dos critérios expostos no Quadro 1.

${ }^{4}$ A atribuição das notas foi realizada coletivamente em reuniões durante o mês de maio de 2013.

${ }^{5}$ Nos protestos de 15 de março de 2015 e na semana anterior a esse evento, a convocatória se deu por Whatsapp, principalmente, durante o panelaço ocorrido no pronunciamento de Dilma Rousseff pelo Dia Internacional da Mulher. Informações disponíveis em: http://zh.clicrbs.com.br/rs/noticias/noticia/2015/03/ convocado-pelo-whatsapp-panelaco-deve-reforcar-protestos-contra-dilma-4714769.html. Acesso em: 22 abr. 2015.
\end{abstract}

\section{REFERÊNCIAS}

ARAÚJO, Willian.

Ciberativismo: levantamento do estado da arte na pesquisa no Brasil. Trabalho apresentado no 5. Simpósio Nacional ABCiber, 16-18 nov. 2011. Udesc/UFSC, Florianópolis. 2011.

ARAÚJO, Willian; FREITAS, Ernani.

"Quanto custa mudar o mundo?" Análise da dimensão discursiva do ciberativismo na Wikileaks. Revista Fronteiras, v.14, n.2, p.110-120. 2012.

ARAÚJO, Rafael; PENTEADO, Cláudio; SANTOS, Marcelo.

Sociedade civil e a e-participação em políticas públicas: o Índice de Participação Política e Influência (IPPI) do Instituto Pólis e do Portal Mobilize Brasil. Paper apresentado no $38^{\circ}$ Encontro Anual da Anpocs, Caxambu-MG. 2014.

ARAÚJO, Rafael; PENTEADO, Cláudio; SANTOS, Marcelo.

Sociedade civil e políticas públicas: o uso da internet pela Rede Nossa São Paulo na articulação política. Paper apresentado no 36. Encontro Anual da Anpocs, 2012. Águas de Lindoia. 2012a.

ARAÚJO, Rafael; PENTEADO, Cláudio; SANTOS, Marcelo.

Sociedade civil organizada e estratégias de articulação: o caso da Rede Nossa São Paulo. Paper apresentado no 8. Encontro da ABCP, 2012. Gramado. 2012b.
ARAÚJO, Rafael; PENTEADO, Cláudio; SANTOS, Marcelo.

O uso das NTICs na formulação e divulgação de políticas públicas: o caso do Ministério da Cultura. Revista Ponto-e-vírgula, n.8, p.88-121. 2010.

AVRITZER, Leonardo.

Instituições participativas e desenho institucional: algumas considerações sobre a variação da participação no Brasil democrático. Opinião Pública, v.14, n.1, p.43-64. 2008.

BORGES, Jussara; JAMBEIRO, Othon. A internet na participação política de organizações da sociedade civil. In: Pinho, José Antonio (Org.). Estado, sociedade e interações digitais: expectativas democráticas. Salvador: Edufba. 2012.

BRUGUÉ, Quinn.

Una administración que habla es una administración que piensa. In: Pérez, Ignacio C. (Coord.).

"Participación Ciudadana"... para una administración deliberativa. España: Dirección General de Participación Ciudadana, Gobierno de Aragón. 2009.

CASTELLS, Manuel.

A sociedade em rede. São Paulo: Paz e Terra. 1999.

CAVALCANTE, Rebeca.

Ciberativismo: como as novas formas de 
comunicação estão a contribuir para a democratização da comunicação. Dissertação (Mestrado - Ciências da Comunicação) Faculdade de Ciências Sociais e Humanas, Universidade Nova Lisboa. 2010.

EGLER, Tamara.

Redes tecnossociais e democratização das políticas públicas. Sociologias, ano 12, n.23, p.208-236. jan.-abr. 2010.

EISENBERG, José.

Democracia Digital. In: Giovanni, Geraldo di; Nogueira, Marco Aurélio (Org.). Dicionário de Políticas Públicas. 2v. São Paulo: Fundap/ Imprensa Oficial. 2013.

FREY, Klaus.

Desenvolvimento sustentável local na sociedade em rede: o potencial das novas tecnologias de informação e comunicação. Revista de Sociologia e Política, n.21, p.165-185. nov. 2003.

GOHN, Maria da Glória.

Teorias dos movimentos sociais: paradigmas clássicos e contemporâneos. São Paulo: Edições Loyola. 2012.

HARDT, Michael; NEGRI, Antonio.

Multidão. Rio de Janeiro: Record. 2005.

JENKINS, Henry.

Cultura da convergência. São Paulo: Aleph. 2008.

KAHN, Richard; KELLNER, Douglas.

New media and internet activism: from the "Battle of Seattle" to Blogging. New Media \& Society, v.6, n.1, p.87-95. 2004.

LEMOS, André.

Cibercultura: tecnologia e vida social na cultura contemporânea. Porto Alegre: Sulina. 2002.

MACHADO, Jorge Alberto.

Ativismo em rede e conexões identitárias:

novas perspectivas para os movimentos sociais. Sociologias, ano 9, n.18, p.248-285. jul.-dez. 2007.

MACINTOSH, Ann; WHYTE, Angus.

Towards an evaluation framework for eParticipation. Transforming Government: People, Process and Policy, v.2, n.1, p.16-30. 2008.

MAIA, Rousiley.

Redes cívicas e internet: efeitos democráticos do associativismo. Logos, v.14, n.2, p.43-62. 2007.

MANIN, Bernard.

The principles of representative government. Cambridge: CUP. 1997.

MATOS, Heloiza.

TICs, internet e capital social. Líbero, ano 10, n.20, p.57-68. 2007.
MEIJER, Albert; BURGER, Nils; EBBERS,

Wolfgang.

Citizens4Citizens: mapping participatory practices on the internet. Electronic Journal of e-Government, v.7, n.1, p.99-112. 2009.

MESQUITA, André Luiz.

Insurgências poéticas: a arte ativista e ação coletiva (1990-2000). Dissertação (Mestrado em História Social) - Faculdade de Filosofia, Letras e Ciências Humanas, Universidade de São Paulo, São Paulo. 2008.

MORAES, Denis.

Comentários - Comunicação virtual e cidadania: movimentos sociais e políticos na internet.

Revista Brasileira de Ciências da Comunicação, v.23, n.2, p.142-155. 2000.

NOGUEIRA, Marco Aurélio.

Participação Política. In: Giovanni, Geraldo di; Nogueira, Marco Aurélio (Org.). Dicionário de Políticas Públicas. 2v. São Paulo: Fundap/ Imprensa Oficial. 2013.

PÉREZ, Ignacio (Org.).

"Participación Ciudadana"... para una

administración deliberativa. Zaragoza: Dirección General de Participación Ciudadana, Gobierno de Aragón. 2009.

PEREZ, Marcos Augusto.

A participação da sociedade na formulação, decisão e execução de políticas públicas. In: Bucci, Maria (Org.). Políticas públicas: reflexões sobre o conceito jurídico. São Paulo: Saraiva. 2006.

PINEZI, Ana Keila Mosca; PENTEADO, Cláudio; SILVEIRA, Sergio Amadeu da.

Cultura, tecnologia, redes e espaço de sociabilidade e socialização. Santo André: Universidade Federal do ABC. 2012.

PINHO, José Antônio G. (Org.).

Estado, sociedade e interações digitais: expectativas democráticas. Salvador: Edufba. 2012.

PUTNAM, Robert.

Comunidade e democracia: a experiência da Itália moderna. Rio de Janeiro: Editora FGV. 2002.

SANTOS, Milton.

A natureza do espaço: técnica e tempo, razão e emoção. São Paulo: Hucitec. 1996.

SCHERER-WARREN, Ilse.

Das mobilizações às redes de movimentos sociais. Sociedade e Estado, v.21, n.1, p.109-130. jan.-abr. 2006.

SENNETT, Richard.

A corrosão do caráter: as consequências pessoais do trabalho no novo capitalismo. Rio de Janeiro: Record. 1999. 
SUBIRATS, Joan.

Otra sociedad, ¿otra política? De "no nos representan" a la democracia de lo común. Barcelona: Icaria Editorial. 2011.
TAMBOURIS, Efthimios et al.

Introducing eParticipation. DEMO-net booklet series, n.1. Disponível em: http://www.ifibconsult.de/publikationsdateien/Introducing eParticipation_DEMO-net_booklet_1.pdf. Acesso em: 10 fev. 2012. 2007.

\section{$\rightarrow \rightarrow \rightarrow<<<$}

